\title{
RELACJA KRONIKI STEFANA RANATOWICZA CRL (1617-1694) NA TEMAT BIOGRAMÓW PREPOZYTÓW KLASZTORU BOŻEGO CIALA KANONIKÓW REGULARNYCH LATERAŃSKICH KONGREGACJI KRAKOWSKIEJ (OD KONRADA ALEMANA DO WIKTORYNA WERESZCZYŃSKIEGO)
}

Autor Kroniki, ksiądz Stefan Ranatowicz, był siedemnastowiecznym kronikarzem i dziejopisarzem zakonu kanoników regularnych laterańskich kongregacji Bożego Ciała w podkrakowskim Kazimierzu. Żył w latach 1617-1694, w latach 1635-1636 studiował na Akademii Krakowskiej, po czym w roku 1636 wstąpił do zgromadzenia kanoników regularnych. W zakonie pełnił wiele funkcji i był zakonnikiem wyróżniających się nie tylko pobożnością, ale i wykształceniem, czego dowodem są pozostawione przez niego dzieła. Jedyny jego utwór wydany drukiem to żywot błogosławionego Stanisława Kazimierczyka, opublikowany w roku 1660 w Krakowie ${ }^{1}$. Kronika o łacińskim tytule rozpoczynającym się od słów: Casimiriae civitatis, urbi Cracoviensi confrontatae, origo $[. . .]^{2}$ powstała w głównej mierze jako zapis dziejów zgromadzenia, natomiast jej część główną, a zarazem zasadniczą, stanowią biogramy kolejnych prepozytów kongregacji krakowskiej, poczynając od Konrada Alemana, pierwszego rządcy tego klasztoru, a kończąc na Wiktorynie Wereszczyńskim, zmarłym w kilka miesięcy po śmierci autora, Stefana Ranatowicza.

Wszystkich biogramów prepozytów omówionych w Kronice jest trzynaście, z tym że ostatni z nich nie został wpisany przez Ranatowicza. Oprócz dziejów i dokonań kolejnych rządców opactwa Bożego Ciała zostały przedstawione także wydarzenia, które miały miejsce w tym czasie i uznane przez kronikarza za warte zanotowania oraz wykazy zakonników zmarłych za rządów poszczególnych prepozytów. Autor nie ograniczał się jednak do

\footnotetext{
S. Ranatowicz, Jasna Pochodnia życia apostolskiego. Żywot świątobliwy Stanisława Kazimierczyka, Kraków 1660; zob. też: A. Witkowska, J. Nastalska, Staropolskie piśmiennictwo hagiograficzne, Lublin 2007.

2 Pełen łaciński tytuł Kroniki brzmi: Casimiriae civitatis, urbi Cracoviensi confrontatae, origo. In eaque ecclesiarum erectiones et religiosorum fundationes, nec non series, vitae, res gestae praepositorum Conventus Canonicorum Regularium Lateranensium S[ancti] Augustini ad Ecclesiam S[acratis]S[imi] Corporis Christi descriptae a Stephano Ranothowicz eiusdem conventus et Ecclesiae Canonico Regul[ari] professo. Kronika ma postać kodeksu o wymiarach 30,2x19,5 cm. Oprawa jest tekturowa, obciągnięta ciemno-brązową skórą cielęcą. Zdobienia są jedynie tłoczone, pozbawione wszelkich złoceń - jest to ornament roślinny w kilku ramkach oraz monogram IHS [Iesus Hominum Salvator]. Na czołowej zewnętrznej stronie oprawy znajduje się również napis wykonany majuskułą: „PRO CONVENTU CAN[ONICORUM] REG[ULARIUM] S[ACRATIS]S[IMI] CORPORIS CHRI[STI]”. Obecnie Kronika znajduje się w zbiorach rękopiśmiennych Biblioteki Jagiellońskiej, BJ, sygn. 3742.
} 
przedstawienia kolei życia prepozytów i okresu sprawowania przez nich urzędu, ale pisał też o cechach charakterów, a nawet oceniał czasem postępowanie prezentowanych postaci. Są to więc $\mathrm{w}$ pewnym sensie portrety. Zredagowane zostały w dość jednolity sposób: na początku podane zostały informacje na temat wyboru na to stanowisko, dalej następowało omówienie sylwetki duchowej i pochodzenia, charakterystyka sprawowanych rządów, wiadomości o konkretnych działaniach oraz wydarzeniach klasztornych, często również zewnętrznych, na końcu zaś informacje dotyczące śmierci. W miarę zbliżania się do czasów kronikarzowi współczesnych, a zatem zwiększania się dostępnych mu materiałów źródłowych, ilość wiadomości zamieszczanych w poszczególnych portretach stopniowo się powiększa. Dlatego też biogramy pierwszych prepozytów są znacznie krótsze i uboższe w informacje i szczegóły niż te ostatnie, zwłaszcza że część opisanych tu wydarzeń autor sam pamiętał lub znał osoby, które były ich świadkami. Nie jest możliwe dokładne przedstawienie w jednym artykule pełnej treści poszczególnych żywotów, a przede wszystkim przytoczenie wszystkich opisanych przez autora historii, dlatego też zostały tu wspomniane jedynie ważniejsze dokonania prepozytów oraz wydarzenia, które wydają się szczególnie interesujące. Nie było również zamiarem autorki przedstawienie faktycznych dokonań kolejnych prepozytów, gdyż temat ten został już gruntownie opracowany przez badaczy zajmujących się historią zgromadzenia kanoników regularnych laterańskich, jak choćby w pracy ks. prof. Kazimierza Łataka Kongregacja Kanoników Regularnych Laterańskich na przestrzeni dziejów. Przedstawione zostały tu jedynie fakty, lub też ich postrzeganie, w świetle Kroniki ks. Stefana Ranatowicza i jego relacji.

Pierwszym prepozytem konwentu kanoników regularnych prepozytury Bożego Ciała był Konrad Alemanus (1405-1425). Ranatowicz pozytywnie oceniał sprawowane przez niego rządy, pochlebnie też wyrażał się o nim samym, pisząc, iż żył dobrze z braćmi w konwencie Bożego Ciała, a także zasługiwał na uznanie zwierzchników³ . W odniesieniu do okresu rządów Konrada Alemana kronikarz powoływał się kilkakrotnie na rękopisy pozostałe po księdzu Krzysztofie Łoniewskim ${ }^{4}$. Z kolei pisząc o budowie kościoła Bożego Ciała, przytaczał wiadomości podane przez Jana Długosza, że rozebrano w tym czasie drewniany kościół parafialny i rozpoczęto budowę nowej świątyni z kamienia i cegły, przy czym wyjaśniał, jak należy te informacje rozumiećs . W jego przekonaniu Konrad zburzył jedynie drewnianą nadbudowę, co pozwoliło na odsłonięcie murów wzniesionych za czasów Kazimierza Wielkiego. Kronikarz odnotował też fakt, iż prepozyt ten praktykował zawieranie konfraterni tak z duchownymi, jak i z osobami świeckimi ${ }^{6}$ oraz podkreślił, że dyscyplinę życia w klasztorze opierał na statutach zakonnych 7 . Śmierć Konrada Alemana Ranatowicz odnotował pod rokiem 1421: Conradus praepositus, in officio praepositurae sexdecem annis expletis, cum omnia a se optime constituta et ordinata, sancte et laudabiliter transegisset, tandem bonis operibus plenus, senio et laboribus confectus, cum ante mortem sacramentis Ecclesiasticis, contra supremum certamen se religiose munivisset, vitam mortalem cum

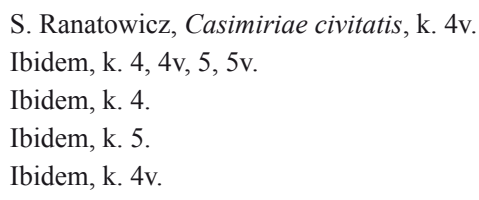


immortali commutavit. Sepultus honorifice, ante maius altare Ecclesiae ${ }^{8}$, gdy w rzeczywistości zmarł on dopiero w roku $1525^{9}$. Ranatowicz popełnił tu zapewne błąd przy odczytywaniu daty z płyty nagrobnej, myląc w gotyckim piśmie jedynkę z czwórką, gdyż śmierć tego prepozyta datowano pierwotnie na rok 1424. Jednak już Krzysztof Łoniewski datował tę śmierć na rok 1425, który ostatecznie należy przyjąć jako właściwy. Część poświęconą Konradowi Alemanowi kończą zapisy z różnych lat, nieuporządkowane chronologicznie, dotyczące spraw rozmaitych, jak na przykład trzęsienie ziemi w Polsce, pożar w Krakowie, napad Tatarów, zaraza lub wielki głód. Często są to tylko krótkie zapisy, jak np. Anno D[omi] ni 1124. Cracovia tota conflagrata; Anno D[omi]ni. Sal in Civitate Bochnensi inventus 1230; Anno D[omi]ni 1310. Pestis et terrae motus $^{10}$. Notatki te sprawiają wrażenie zapisów rocznikarskich, nie udało się jednak ustalić źródła ich pochodzenia. Jest możliwe, że Stefan Ranatowicz korzystał z dokumentów zgromadzonych w archiwum miejskim, zwłaszcza biorąc pod uwagę fakt, iż w klasztorze kanonickim na Kazimierzu bywał Jan Fox, pełniący funkcję kanclerza kapituły krakowskiej.

Kolejnym prepozytem był Jan Austriak (1425-1429). Stefan Ranatowicz nie poświęcił mu zbyt wiele uwagi, a informacje podane na temat jego działalności są dość skąpe. Autor tłumaczy to niewielką ilością materiałów pozostawionych przez dawnych zakonników: $\mathrm{Ca}$ etera quae Ioannes Austriacus, praepositus, fecit, antiqui fratres non scripsere ${ }^{11}$. Zanotował jednak, że Jan Austriak zawierał liczne konfraternie z innymi klasztorami kanonickimi i wymienia tu placówki w Trzemesznie, Mstowie i Kaliszu. Ponadto za rządów tego prepozyta klasztor otrzymał potwierdzenie jego fundacji od papieża Marcina $\mathrm{V}^{12}$. W sprawie budowy kościoła nie podał żadnych szczegółów ponad to, że były kontynuowane prace rozpoczęte przez Konrada Alemana. W tekście znajduje się również informacja o wprowadzeniu przez Jana Austriaka zwyczaju codziennego czytania w konwencie kazimierskim statutów zakonnych opracowanych przez Piotra Klaretę z domu w Rudnicach ${ }^{13}$. Ranatowicz ocenił, że Jan Austriak dbał bardzo właśnie o regułę zakonną i sprawowanie obrządku' ${ }^{14}$. Śmierć prepozyta datował na rok $1428^{15}$. Poza tym, znajdują się tu również zapisy rocznikarskie z różnych lat. Są to zarówno wydarzenia współczesne Janowi Austriakowi, jak i z okresów dużo wcześniejszych, na przykład z roku 1191 czy 1241. Tematyka tych notatek jest bardzo różna, jak choćby na przykład informacje o skróceniu okresu postu od roku 1248 lub na temat darowania klasztorowi krakowskiemu łąk, czy też morderstwa popełnionego w kościele św. Franciszka przez obywateli krakowskich. Podaje również informację „,za historykami piszącymi o sprawach polskich”, że w początkach Królestwa Polskiego nie spisywano

\footnotetext{
8 „Prepozyt Konrad, przeżywszy pełnych szesnaście lat sprawując prepozyturę w sposób święty i godny pochwały, gdy wszystkie sprawy jak najlepiej postanowił i uporządkował, pełen dobrych dzieł i zamierzeń, starością i pracą zmorzony, kiedy przed śmiercią, na ostatnią drogę, sakramentami świętymi pobożnie się zabezpieczył, życie ziemskie zamienił na życie wieczne. Pochowany zaszczytnie przed wielkim ołtarzem w kościele”, tłum. własne autorki artykułu, zob. ibidem, k. 5v.

9 K. Łatak, Kongregacja krakowska kanoników regularnych laterańskich na przestrzeni dziejów, Kraków 202, s. $175-176$.

10 S. Ranatowicz, Casimiriae civitatis, k. 5v.

11 Ibidem, k. 6v.

12 Ibidem, k. 6.

13 Ibidem, k. 6v.

14 Ibidem, k. 6.

15 Ibidem, k. 6v.
} 
dziejów, ponieważ Polacy nie potrafili pisać16. Spośród historyków kronikarz najczęściej powołuje się tu na Jana Herburta i Marcina Kromera.

Następnie Jana Austriaka na stanowisku prepozyta zastąpił Grzegorz (1428-1439). Według Ranatowicza wybrano go jednogłośnie ${ }^{17} \mathrm{i}$ określił go jako vir singularis virtutis et doctri$n a e^{18}$. Wiadomości zamieszczone w Kronice na temat działań podjętych przez Grzegorza nie są zbyt obszerne, pojawia się jednak informacja, że powiększył pomieszczenia klasztorne o infirmerię, w której wzniesiony został również ołtarz, aby chorzy łatwiej mogli wysłuchać mszy świętej ${ }^{19}$ oraz nowe miejsce na bibliotekę. Znaleźć można także informację o zawarciu konfraterni z klasztorami cysterskimi. Śmierć Grzegorza została odnotowana w roku 1439. Po życiorysie następują, jak w innych żywotach, notatki odnoszące się do wydarzeń z różnych lat i bez ścisłego porządku chronologicznego. Do ciekawszych z nich należy między innymi informacja o wprowadzeniu do Polski w roku 1300 srebrnej monety, nazywanej czeskim groszem, która według tej relacji, miała być gdzieniegdzie w użyciu w Krakowie jeszcze w roku $1670^{20}$. Na uwagę zasługują też zapiski odnośnie fundacji klasztorów kanonickich w Polsce oraz ich przekazania zakonowi: w Trzemesznie w roku 965, a następnie w Czerwińsku, w roku 1222 w Mstowie, a w roku 1358 w Kaliszu. Ponadto znajduje się tu kilka zapisów odnoszących się do Litwy, na przykład legenda o powstaniu Wilna ${ }^{21}$. Według relacji Guagninusa, na którą powoływał się Ranatowicz, książę Giedymin, wódz litewski, w czasie polowania, gdy schronił się przed nocą na górze nad rzeką Wilną, miał sen. Przyśnił mu się żelazny wilk, a w jego wnętrzu wiele innych wilków. Sen ten został wyjaśniony przez kapłana Ledziejko, który zajmował się wróżbiarstwem i przepowiadaniem przyszłości. Wilk miał oznaczać silne i sławne miasto, natomiast inne wilki w jego wnętrzu, ludność owego miasta. Dlatego za jego radą Giedymin postanowił na owej górze wybudować miasto i nazwać je Wilno, od nazwy płynącej wokół wzgórza rzeki oraz przenieść tam swoją siedzibę z Troków. Działo się to w roku 1305. Natomiast Ledziejko, w uznaniu swych zasług, mianowany został doradcą w mającym powstać mieście i zyskał nazwisko Radivil, skąd wywodził się znamienity ród, jeden z najświetniejszych w Rzeczypospolitej. Na szczególną uwagę zasługuje notatka na marginesie karty 9, informująca o znajdujących się tu wzmiankach na temat początków rodu Radziwiłłów, a to dlatego, iż została ona wpisana inną ręką, z pewnością nie przez Stefana Ranatowicza ${ }^{22}$. Dalej jest jeszcze kilka wpisów odnośnie wydarzeń na Litwie, jak choćby historia osadzenia w Wilnie grupy Tatarów pokonanych przez księcia litewskiego Witolda podczas jednej z jego wypraw; mieli oni przebywać tam jeszcze w czasach kronikarzowi współczesnych, tworząc odrębną wspólnotę, wyznając swoją religię i posiadając własną chorągiew, noszoną w bitwach ${ }^{23}$. Interesujący jest rów-

\footnotetext{
16 Historici qui de rebus polonorum scripserunt narrant Polonos in principio Regni res gestas non scripsisse, eo quod nullam notitiam litterarum habuerunt, zob. ibidem, k. 7.

17 Ibidem, k. 8.

18 Ibidem, k. 8 .

19 Ibidem, k. 8 .

20 Anno Virginei partus 1300. Venceslaus Rex Poloniae et Bohemiae, primus Monetam argenteam, grossos scilicet Bohemicos, in Poloniam intulit, qui ad huc in usu Cracoviae passim habentur, ad Annum 1670 et vocabatur Ceski grosz, zob. ibidem, k. 9.

21 Ibidem, k. 9.

22 Radiviliarum familiae et stirpis origo, zob. ibidem, k. 9.

23 Ibidem, k. 9-9v.
} 
nież fragment mówiący o buncie obywateli wileńskich przeciwko mianowaniu przez króla Zygmunta III tamtejszym biskupem Bernarda Maciejowskiego, który pochodził z rodziny polskiej. Ostatecznie mianowany został Benedykt Woyna, z pochodzenia Litwin, a na królu mieszkańcy Wilna wymogli obietnicę powierzania podobnych godności osobom pochodzenia litewskiego ${ }^{24}$. Wśród innych wiadomości Ranatowicz podał jeszcze informacje na temat trzęsień ziemi w Italii w roku 1618 i 1627; powoływał się przy tym na Pawła Piaseckiego.

Kolejnym prepozytem był Gaspar (1440-1464). Ranatowicz podał rok 1467 jako datę jego śmierci, podczas gdy faktycznie już w roku 1464 nie żył, albo mógł też zrezygnować wcześniej z urzędu ${ }^{25}$. Pomimo iż Gaspar sprawował rządy długo, bo przez dwadzieścia kilka lat, nie ma zbyt wielu informacji na temat jego dokonań. Na pierwszy plan wysuwają się, rozpoczęte przez poprzedników, prace przy kontynuacji budowy kościoła Bożego Ciała, którym oddawał się z gorliwością ${ }^{26}$. Wśród różnych wydarzeń Ranatowicz wspomniał między innymi fundację klasztoru kanoników regularnych w Kurozwękach w roku 1451 oraz, w tym samym roku, klasztoru franciszkanów na Stradomiu, przy czym powołał się na świadectwo Macieja z Miechowa ${ }^{27}$. Według tej relacji, w roku 1454 miał zostać ufundowany klasztor kanoników w Kłobucku, czego dokonał historyk Jan Długosz. Poza tym, w rozdziale poświęconym Gasparowi, jest mowa o wojnie świętej przeciw Turkom podjętej przez papieża Piusa II w roku 1464 oraz o pogromach żydowskich na Kazimierzu. Wspomina też Ranatowicz przypadek powołania w Krakowie około roku 1456 trzech biskupów w jednym czasie oraz dwa wydarzenia niezwykłe, jak urodzenie przez pewną kobietę na Węgrzech ośmiorga dzieci równocześnie oraz przypadek wyrośnięcia nowych zębów osobie blisko dziewięćdziesięcioletniej, matce arcybiskupa Stanisława Karnkowskiego: Medicus, Joannes dictus Oczko, vir in arte sua solertissimus, narravit, quod Matri Stanislai Karnkowski Archiepiscopi Gnesnensis accidisset, ipsi enim nonagenariae, dentes novis crevisse ${ }^{28}$.

Po śmierci Gaspara prepozytem został mianowany Jakub z Wadowic (Vadovius), który sprawował rządy w latach 1464-1495. Ranatowicz określił moment jego śmierci na rok 1477, ale trudno stwierdzić czym się kierował przy podaniu tej daty, wiadomo bowiem, że prepozyt żył jeszcze wiele lat później i nazwisko jego figuruje w odnalezionych dokumentach ${ }^{29}$. Zaraz po swej nominacji Jakub zajął się pracami przy budowie kościoła, kontynuując dzieło poprzednich rządców oraz wzbogacając wnętrze świątyni czterema nowymi ołtarzami i stawiając drewnianą dzwonnicę ${ }^{30}$. Poza tym, za rządów Jakuba Vadoviusa, został ufundowany klasztor kanoników w Kraśniku w roku 1468. Odnotowany został również fakt wprowadzenia w roku 1472 zakonu paulinów do kościoła św. Stanisława na Skałce w Krakowie. Udział w tej fundacji miał Jan Długosz, który następnie został tam pochowany ${ }^{31}$. Ranatowicz powołał się tu na opis Macieja z Miechowa i wspomniał także, że na Skałce złożono również ciało błogosławionej Świętosławy, której żywot, spisany według podań Joachima Bielskiego

\footnotetext{
24 Ibidem, k. 9v.

25 K. Łatak, Kongregacja krakowska kanoników regularnych laterańskich, s. 187-188.

26 S. Ranatowicz, Casimiriae civitatis, k. 10.

27 de quo Miechoviensis historicus Polonus, in haec verba scribit, zob. ibidem, k. 10v.

28 Ibidem, k. 133.

29 K. Łatak, Kongragacja kanoników regularnych laterańskich, s. 192-193.

30 S. Ranatowicz, Casimiriae civitatis, k. 12

31 Item ibidem depositum est corpus Joannis Dlugosii, Canonici Cracoviensis et Historici Poloni, et huius monasterii Fundatoris, Anno Domini 1480 defuncti, zob. ibidem, k. 12v.
} 
i Macieja z Miechowa, zamieścił w rozdziale poświęconym dokonaniom Jakuba Vadoviusa. Świętosława była niezwykle pobożną mieszkanką Kazimierza, która po śmierci męża zajęła się dobroczynnością. Na swego szczególnego patrona wybrała sobie świętego Stanisława, biskupa i męczennika, i gdy modliła się przy jego grobie na Skałce, św. Stanisław ukazał jej się $\mathrm{w}$ otoczeniu orszaku innych świętych i polecił jej pójść do biskupa krakowskiego Lamberta z poleceniem przeniesienia jego ciała do katedry w Krakowie. Błogosławiona Świętosława podjęła działania w tym kierunku; zmarła w roku 1083 w opinii świętości i została pochowana na Skałce. W rozdziale poświęconym Jakubowi z Wadowic znalazły się jeszcze wiadomości dotyczące spraw różnych, polskich, jak i odnoszące się do sytuacji w Europie, jak choćby wprowadzenie nowego kalendarza przez papieża Grzegorza XIII w roku 1582, czy też zakazu czytania Talmudu przez Żydów wydanego w roku 1593 przez papieża Klemensa VIII oraz odnalezienia w Rzymie w roku 1595 relikwii świętej Cecylii. Za źródło swych informacji Ranatowicz podał kronikę Pawła Piaseckiego ${ }^{32}$. Jako wydarzenie warte wspomnienia w Polsce został odnotowany wyjątkowo duży wylew Wisły, który miał miejsce w roku 1475, kiedy woda wlewała się nawet do wnętrz kościołów i pozrywane zostały mosty łączące Kazimierz z Krakowem. Oprócz tego, wśród klęsk żywiołowych jest wymieniany powtarzający się w różnych latach głód, zarazy oraz straszna susza w roku 1469.

Biogram kolejnego prepozyta, którym był Andrzej (1495-1505), zawiera informacje, które właściwie powinny zostać podane przy dokonaniach jego poprzednika, Jakuba Vadoviusa, ponieważ, jak wcześniej stwierdzono, Ranatowicz błędnie określił datę śmierci tego ostatniego. Tak więc Andrzej rozpoczął sprawowanie funkcji prepozyta dopiero w roku 1495, a nie w 1477. W związku z tym historia dotycząca planowanej fundacji klasztoru Kartuzów na Kazimierzu w roku 1478, o której pisał Jan Długosz, a która nie doszła do skutku w wyniku sprzeciwu mieszkańców, musiała mieć miejsce jeszcze za rządów Jakuba z Wadowic. W kolejnym zapisie Ranatowicz podał informację, że w roku 1489 zmarł błogosławiony Stanisław Kazimierczyk z klasztoru kanoników regularnych na Kazimierzu: Anno Domini 1489. B[eatus] Stanislaus Casimiritanus, vir sanctitate et doctrina illustris, ex claustro Casimiriensi Canonicorum Regularium, in caelos abiit ${ }^{33}$. Kronikarz napisał również w tym miejscu, że w roku 1670 on sam wydał żywot błogosławionego Stanisława swojego autorstwa ${ }^{34}$, przy czym popełnił pomyłkę w zanotowaniu roku, jako że wiadomo, iż w rzeczywistości praca ta została opublikowana w roku 1660, czyli o dziesięć lat wcześniej. Jednakże, pomimo pomyłki w datowaniu, fragment ten stanowi dowód na to, iż ta część Kroniki została spisana z pewnością już po tym wydarzeniu, jako że tekst jest w tym miejscu ciągły i nie ma możliwości, aby taki dopisek dodano później. Żywot zamieszczony w tym rozdziale jest krótki i ogranicza się jedynie do najistotniejszych wydarzeń z życia Stanisława Sołtysa, zwanego Kazimierczykiem. Fragment ten nosi tytuł Vita et obitus $B[e-$ ati] Stanislai Casimiritani, Canon[ici] Regul[aris] professi Conven[tus] Casimirien[sis]. Zawiera informacje również o pochodzeniu i rodzicach błogosławionego, który na chrzcie otrzymał imię świętego Stanisława, biskupa i męczennika. Od początku odznaczał się dużymi zdolnościami, najpierw wybijając się w szkole parafialnej przy kościele Bożego Ciała, a następnie uzyskując kolejne stopnie na Akademii Krakowskiej, gdzie ukończył

32 Ibidem, k. 13v.

33 Ibidem, k. 14v.

34 Ibidem, k. 14v. 
studia w zakresie filozofii oraz teologii, zdobywając ostatecznie tytuł doktora. Będąc zaś człowiekiem wielkiej pobożności, postanowił wstąpić do zakonu kanoników regularnych żyjących w klasztorze Bożego Ciała na Kazimierzu według reguły świętego Augustyna. Tu także wyróżniał się swym wykształceniem, pełniąc liczne odpowiedzialne funkcje w zgromadzeniu, powierzane mu przez przełożonych, oraz gorliwością w pobożności. Umartwiał często swoje ciało i spędzał dnie i noce na modlitwie i medytacjach. Według tej relacji, gdy modlił się przy grobie świętego Stanisława, ukazała mu się Matka Boża wraz ze swym Synem i świętym Stanisławem i przyrzekła mu nagrodę życia wiecznego za jego pobożne życie ${ }^{35}$. Przed samą śmiercią jeszcze miał mu się ukazać Chrystus w otoczeniu świętych polskich i wezwać go do siebie ${ }^{36}$. Co interesujące, słowa wypowiadane rzekomo w czasie objawień nie są powtórzone dosłownie w żywocie błogosławionego Stanisława stanowiącym osobne dzieło, choć sens oddają ten sam; różnice są wprawdzie niewielkie, ale jednak istnieją, co świadczyłoby o tym, że Ranatowicz nie przekopiował tego fragmentu z jednego żywota do drugiego. Zmarł 3 maja 1489 roku w opinii świętości. Skoro zaczęto zauważać cuda, które działy się za jego wstawiennictwem, wydobyto po kilku latach jego szczątki i złożono w nowej trumnie w innym miejscu kościoła Bożego Ciała. Ranatowicz podaje, że był tam taki napis: Hoc conclusa iacent Divi patris ossa sepulchro Stanislai, hac Casimiria de gente creati, Cuius gestorum miranda cerne trophea ${ }^{37}$. W roku 1635 prepozyt Marcin Kłoczyński polecił po raz kolejny przenieść relikwie błogosławionego Stanisława i umieścić w grobowcu w ołtarzu w lewej nawie bocznej kościoła ${ }^{38}$; kamienna tablica tam wmurowana znajduje się w tym miejscu do chwili obecnej. W czasach Ranatowiczowi współczesnych również modlono się przy grobie tego świętego i wypraszano za jego wstawiennictwem liczne łaski.

Po żywocie Stanisława Kazimierczyka następują zapisy rocznikarskie. Między innymi opisał Ranatowicz historię przeniesienia się Żydów na Kazimierz w roku 1492 po wielkim pożarze w Krakowie, w którym spłonęły ich siedziby. Żydzi od tego czasu trzy razy w roku przynosili prepozytowi i kapłanom wonne zioła i korzenie. Zapis ten zasługuje na uwagę, ponieważ autor uczynił odnośnik na marginesie karty, odsyłający do wyjaśnień w tej sprawie aż na koniec Kroniki, do karty 152: Aromata a Iudaeis. Vide fol. 152. W podanym miejscu znajduje się wyjaśnienie takiego postępowania, a mianowicie miało to być niejako zadośćuczynienie za zajęcie terenów, z których, gdyby były zamieszkane przez ludność chrześcijańską, kościół miałby zapewnione dochody. Przy czym tekst na karcie 152 również jest opatrzony odsyłaczem, tym razem do karty 15: jest to potwierdzenie dużej dokładności i staranności Ranatowicza przy spisywaniu Kroniki. Następnie zapisane zostało, że w roku 1505 wybrano nowego prepozyta, początkowo jako koadiutora dla Andrzeja, który, z powodu choroby i podeszłego wieku, nie mógł dłużej sprawować swej funkcji ${ }^{39}$. Wyznaczony został Benedykt, jednak według Ranatowicza pełnił on urząd tylko przez rok, jeszcze za życia Andrzeja; zrezygnować miał sam i dlatego kronikarz nie umieścił jego biogramu wśród

\footnotetext{
35 Gaudeo, fili Stanislae, de insigni tua ista devotione, qua me et S. Stanislaum prosequeris; viriliter age, te enim una cum sanctis meis, merces copiosa expectat $i$ caelis, zob. ibidem, k. 15.

36 Surge (inquit) et festina, fili mi Stanislae, hodie enim mecum eris in Paradiso, zob. ibidem, k. 15.

37 „Tu złożone w grobowcu spoczywają szczątki błogosławionego ojca Stanisława, zrodzonego z tego rodu kazimierskiego, którego podziwu godny pomnik zauważ”, tłum. własne autorki.

38 Ibidem, k. $15 \mathrm{v}$.

39 Ibidem, k. 16.
} 
innych prepozytów ${ }^{40}$. W rzeczywistości Benedykt sprawował funkcję prepozyta przez ponad dziesięć lat (1505-1518). Śmierć Andrzeja zaś Ranatowicz datował na rok 1505.

Tak więc część informacji zawartych w żywocie kolejnego rządcy opactwa Bożego Ciała, którym został Piotr (1518-1526), odnosi się jeszcze do prepozytury pominiętego w wykazie Benedykta. Zresztą sam Ranatowicz, pisząc o przejęciu rządów przez Piotra, wymienia dwóch poprzednich prepozytów ${ }^{41}$. Na temat jego działalności nie zanotował wiele, tłumacząc się brakiem stosownych danych ze strony dawnych pisarzy i zakonników; twierdził, że woli czegoś nie napisać wcale, niż podać do wiadomości informacje nieprawdziwe: Hic praepositus, quae gessit per viginti annos et amplius, non scripsere antiqui, sed cum id non scribant, ideo etiam ego malui ignorare potius, quam divinare ${ }^{42}$. W wyniku pomyłki w sprawie sprawowania prepozytury przez Benedykta, Ranatowicz i tu błędnie podał okres rządów przypadający na Piotra, był on bowiem prepozytem jedynie przez lat osiem, a nie dwadzieścia jeden. Jednak w ogólnym rozrachunku okres jego rządów kronikarz uznał za niezbyt szczęśliwy dla klasztoru kazimierskiego. Spośród wymienionych wydarzeń żadne nie wydaje się szczególnie doniosłe, głównie opisane zostały wypadki powodzi, pożaru, głodu lub zarazy. Śmierć Piotra według Ranatowicza miała miejsce w roku 1526. Dość obszernie pisał też na temat prób zawierania małżeństw przez księży, podając przykłady konkretnych nazwisk, natomiast o zjawisku ,siania” herezji przez Lutra jedynie wspomina w jednym wersie ${ }^{43}$. Wspomniał jednak o rozprzestrzenianiu się myśli heretyckich w Polsce. Zamieścił też pewne informacje na temat papieża Sykstusa V oraz ogromnego majątku biskupa krakowskiego Andrzeja Lipskiego, powołując się na kronikę Pawła Piaseckiego.

Kolejnym z prepozytów był Jan Niczkonius (1526-1544). Na temat jego rządów, które ocenił jako pomyślne dla zgromadzenia, napisał Ranatowicz już nieco więcej. Wysoko ocenił jego charakter i wykształcenie ${ }^{44}$, wymienił też szereg zasług położonych przez niego dla klasztoru, jak na przykład wzbogacenie biblioteki zakonnej własnymi książkami oraz przeniesienie na nowe miejsce szkoły parafialnej działającej przy kościele Bożego Ciała. Warto zauważyć, że choć dłuższy tekst polski pojawia się dopiero na dalszych kartach Kroniki, w tym miejscu wystąpił po raz pierwszy w tekście zwrot polski, a mianowicie Ranatowicz zanotował, iż od tego właśnie czasu o miejscu dawnej lokalizacji szkoły mówiono „Stara szkoła $^{45}$ ". Wśród zwykłych opisów klęsk żywiołowych oraz wydarzeń różnych, Ranatowicz wspomniał o wypadku spalenia na rynku w Krakowie żony jednego z radców miasta, na którą to karę została skazana za przejście na wiarę żydowską; incydent ten miał miejsce w roku $1539^{46}$. Jan Niczkonius zmarł w roku 1544. Po odnotowaniu jego śmierci, kronikarz dość obszernie opisał przypadek pewnego szlachcica, Jakuba Melszyńskiego z Brzezin, który w otoczeniu dwunastu towarzyszy, podawał się za Chrystusa, a jego kompani za apostołów; wędrowali oni po Polsce, dopuszczając się licznych grabieży i świętokradztw, aż wreszcie zostali pojmani i ukarani na Śląsku. Wydarzenie to miało miejsce za panowania Zygmunta

40 Ibidem, k. 16.

41 In locum Andreae, vel potius Benedicti praepositi, subrogatus est omnium votis Petrus [...], villarum sub Andrea et Benedicto procurator, zob. ibidem, k. 17.

42 Ibidem, k. 17.

43 Anno D[omi]ni 1517. Lutherus haeresim seminare incepit, Vitembergae, zob. ibidem, k. 18.

44 Ibidem, k. 19.

45 Ibidem, k. 19.

46 Ibidem, k. 19v. 
Starego, w roku 1507, natomiast przy opisie autor powołał się na Marcina Bielskiego i jego Annales Polonorum ${ }^{47}$.

Kolejny portret poświęcony został Stanisławowi Niedzieli (1544-1582). Rządy jego Ranatowicz ocenił pozytywnie, podkreślając zapobiegliwość i duży wkład w rozbudowę i wyposażenie kościoła Bożego Ciała. Na marginesie karty określił prepozyta mianem operosus pater familias ${ }^{48}$. W opisie zasług tego prepozyta powołał się na rękopisy ks. Krzysztofa Łoniewskiego. Przypisywał Stanisławowi Niedzieli otoczenie murem ogrodu klasztornego, rozbudowywanie nieruchomości klasztornych w Krzyszkowicach, Swoszowicach i Kamieniu, a także zakup od Węgrów pozłacanych krzyży i nowych ksiąg liturgicznych, jak również wybudowanie nowej dzwonnicy, w miejsce zniszczonej przez pożar. Miał też zakupić dwa nowe dzwony o nazwach Stanislaus (inaczej Dziad) i Augustinus (inaczej Baba), których używano jeszcze w czasach Ranatowiczowi współczesnych: [...] novasque campanas, praecipue duas Maiores, unam quam vocabatur hucusque communi cognomine Dziad, et alio nomine Stanislaus: et alteram Minorem dictam Baba, alio nomine Augustinus, comparavit ${ }^{49}$. Wspomniana została też sprzedaż Żydom dwóch kamienic w sąsiedztwie kościoła św. Wawrzyńca, wraz z ogrodami, za cenę dwóch tysięcy florenów w złocie ${ }^{50}$ oraz przekazanie, również Żydom, wielu innych obiektów i terenów na Kazimierzu. Na uwagę zasługuje też wzmianka dotycząca sprawy klasztoru w Kurozwękach. Otóż po śmierci tamtejszego prepozyta Franciszka kościół został kanonikom odebrany przez Mikołaja Lanckorońskiego, właściciela ziemskiego w Kurozwękach, nazwanego przez Ranatowicza heretykiem, znaczną część zasobów klasztoru i kościoła zrabowano, przejęto również ziemie należące do konwentu, natomiast dwaj pozostali tam bracia zostali wygnani i powrócili do Krakowa. Dopiero po upływie około trzydziestu lat, prepozyt klasztoru Bożego Ciała, przedłożył tę sprawę przed trybunałem królewskim, w wyniku czego nakazano oddać klasztorowi kurozwęckiemu kościół i jego posiadłości, co jednak znacznie przeciągnęło się w czasie, tak że prepozytem w odzyskanym klasztorze został dopiero Paweł Łyczko ${ }^{51}$. Opisany też został ogromny pożar, który w roku 1556 strawił znaczną część Stradomia i Kazimierza. Ranatowicz wyraźnie napisał, iż wtedy właśnie spłonęła dzwonnica przy kościele Bożego Ciała i w jej miejsce Jan Niczkonius kazał wybudować nową, przy czym zaznaczył w tekście, że już wcześniej zostało to wspomniane ${ }^{52}$. Jako moment śmierci Stanisława Niedzieli podany został rok 1582. Bezpośrednio po tekście jego biogramu został umieszczony krótki żywot świątobliwego męża Walentyna Kuczborskiego, również z zakonu kanoników regularnych na Kazimierzu ${ }^{53}$. Zakonnik ten wysłany został do klasztoru bychowskiego na Litwie. Odznaczał się wyjątkową świętością życia oraz niestrudzonym głoszeniem Słowa Bożego ${ }^{54}$. Upodobał sobie życie pustelnicze i przez pewien czas przebywał w oddaleniu od

47 Ibidem, k. 20-20v.

48 Ibidem, k. 21.

49 Ibidem, k. 21.

50 Ibidem, k. 21.

51 Ibidem, k. 21v.

52 Sub id tempus, turris cum quattuor campanis Ecclesiae nostrae SS. Corporis Christi combusta, in quo loco, Stanislaus Niedziela praepositus, turrim novam, cum campanis, ut supra dictum est, excitavit et comparavit, zob. ibidem, k. 21v.

53 Vita Valentini Kuczborski Canon[ici] Regul[aris], zob. ibidem, k. 23.

54 Ibidem, k. 23. 
klasztoru, niedaleko miejscowości Ozierany, żywiąc się jedynie chlebem otrzymanym od okolicznych mieszkańców. Później jednak został przywołany z powrotem do klasztoru i tam żył w zimnej celi, oddając się lekturze Pisma Świętego. Umarł w roku 1624 w klasztorze bychowskim. Opisując jego życie, Ranatowicz powołał się na Krzysztofa Łoniewskiego oraz Piotra Jacka Pruszcza. W dalszej części rozdziału opisane zostały wydarzenia różne, między innymi wspomniano o uroczystościach jubileuszowych w Rzymie w roku 1624, celebrowanych przez papieża Urbana VIII, podczas których był obecny i brał w nich udział książę Władysław, późniejszy król Polski Władysław IV ${ }^{55}$. Ranatowicz pisał też o dysputach prowadzonych w Toruniu w roku 1625 przez katolików oraz, jak ich określił, disidentes in religione Christiana.

Po śmierci Stanisława Niedzieli prepozytem został wybrany Stanisław Maniecki (15821611). Ranatowicz podkreślił dość mocno jego udział w sprawach państwowych oraz kościelnych; pracował mianowicie u boku biskupa krakowskiego, Piotra Myszkowskiego, towarzyszył mu także na sejm w Warszawie, gdzie miał otrzymać również dokument potwierdzający przywileje klasztoru kazimierskiego ${ }^{56}$. Odnotowany też został fakt wygrania przez Stanisława Manieckiego procesu i odzyskania kościoła i budynków klasztornych w Kurozwękach w roku 1593. Nie ma natomiast w Kronice danych odnośnie kontynuacji prac przy budowie kościoła, zamieszczono jedynie informację na temat elementów zdobniczych. Wiadomo z kolei o zniszczeniach dokonanych w kościele przez pożar w roku 1595, kiedy to spłonęły kościelne organy. Ranatowicz generalnie widział w tym prepozycie „człowieka szlachetnie urodzonego ${ }^{57 ،}$, jednakże na okres jego rządów przypada sporo nieporozumień i zamieszania $\mathrm{w}$ zgromadzeniu, nie tylko $\mathrm{w}$ związku $\mathrm{z}$ osobą narzuconego koadiutora w okresie choroby Manieckiego. Ów bowiem zaczął dopuszczać do siebie zbyt wielu swoich krewnych i osoby ze sobą związane, niewłaściwie też dbał o majątek klasztorny i nie przestrzegał starannie reguły zakonnej, co powodowało niezadowolenie i sprzeciw wielu braci z zakonnej wspólnoty, a w konsekwencji prowadziło do sporów i niesnasek ${ }^{58}$. Do poważnych problemów doszło, gdy w roku 1605 Stanisław Maniecki został sparaliżowany, a wiadomo, że już znacznie wcześniej poważnie chorował, w wyniku czego nie był w stanie właściwie sprawować swojej funkcji ${ }^{59}$. Wtedy właśnie został przydzielony koadiutor w osobie Pawła Łyczki, sprawującego jeszcze wtedy funkcję prepozyta w klasztorze kurozwęckim, jednakże zgromadzenie nie chciało przyjąć tego wyboru i wynikło stąd wiele nieporozumień i niepokojów. Zakonnicy wielokrotnie odwoływali się od tej decyzji do Stolicy Apostolskiej, aż po licznych interwencjach, w roku 1608, biskup krakowski Piotr Tylicki zdecydował się na mianowanie Tomasza Zdunka z klasztoru w Kłobucku administratorem we wspólnocie kazimierskiej ${ }^{60}$. Przy okazji jednego z odwołań, w roku 1607, jako poseł ze strony zgromadzenia, został wysłany do Rzymu Adam Sibovius. Jednak zmarł w drodze złożony chorobą, a jako że odznaczał się wyjątkową świętością życia ${ }^{61}$, otoczony był wielkim szacunkiem ze

\footnotetext{
Ibidem, k. 23.

Ibidem, k. 24.

Ibidem, k. 24.

Ibidem, k. 24v.

Ibidem, k. 24v.

0 Ibidem, k. 25v.

61 Ibidem, k. 25.
} 
strony współbraci. Zmarł w opinii świętości i został pochowany w kościele Bożego Ciała, natomiast przy jego grobie zaczęły mieć miejsce wydarzenia niezwykłe; najczęściej zdarzały się przypadki uwolnienia od złego ducha osób opętanych. Pisząc o osobie Siboviusza, Ranatowicz powoływał się na relację Jana Gelazego Żórawskiego, również kanonika regularnego i egzorcystę ${ }^{62}$. Fragment dotyczący Adama Siboviusza Ranatowicz sam traktował niemal jako dygresję; po zakończeniu tej relacji napisał: Sed ad praepositum nostrum redeamus ${ }^{63}$. Pomimo wyboru nowego administratora, sprawa nieporozumień wynikłych z narzucenia wspólnocie koadiutora zakończyła się tak naprawdę w momencie śmierci Pawła Łyczki w roku 1610. Natomiast sam prepozyt Stanisław Maniecki zmarł niewiele później, w roku 1611. Rządy jego zostały przez Ranatowicza osądzone niezbyt pochlebnie. Po pogrzebie, podczas posiedzenia kapituły zdecydowano, aby w przyszłości wybrać prepozyta spoza wspólnoty kazimierskiej i delegacja udała się z taką prośbą do biskupa. Ranatowicz jeszcze w tym rozdziale, poświęconym w zasadzie dokonaniom Stanisława Manieckiego, zamieścił informację o wyborze Marcina Kłoczyńskiego na kolejnego prepozyta ${ }^{64}$, chociaż też opatrzył ten fragment dodaną na końcu uwagą: Sed unde digressi sumus revertamur. Nie był on w ogóle zakonnikiem, dopiero po swej nominacji przywdział strój kanoników regularnych, a dopiero w sześć lat od wyboru złożył profesję zakonną ${ }^{65}$. W dalszej części rozdziału dość obszernie zostały opisane obchody jubileuszowego roku 1603, za króla Zygmunta III, liczne uroczystości kościelne i państwowe, które miały miejsce w Krakowie z tej okazji. Szczególną uwagę zwrócił też kronikarz na ogromną ilość ludzi przybyłych zewsząd do Krakowa, tak, że trudno im było pomieścić się nie tylko w samym mieście, ale i na Kazimierzu, a także w podkrakowskich miejscowościach ${ }^{66}$. Odnotował również fakt znalezienia w kościele św. Anny w Krakowie szczątków błogosławionego Jana Kantego. Wśród wydarzeń różnych przytoczonych na końcu znajdują się między innymi fragmenty pisane w języku polskim.

Kolejny prepozyt, Marcin Kłoczyński (1612-1644), jak już wspomniano, został wybrany spoza kręgu kanoników regularnych. Ranatowicz pozytywnie ocenił jego starania już na początku biogramu, twierdząc, że pracował wytrwale, w miarę sił swoich ${ }^{67}$. Przede wszystkim doprowadził do końca przebudowę budynku kościoła $\mathrm{z}$ drewnianego w murowany, a szczególnie, za jego rządów właśnie, zostało przebudowane wnętrze kościelne. Oprócz prac remontowych wykonano również szereg zabiegów zdobniczych, zakupione zostały okazałe i ozdobne sprzęty, a także księgi i naczynia oraz szaty liturgiczne. W czasie tego remontu właśnie zostały przeniesione do nowego ołtarza szczątki błogosławionego Stanisława Kazimierczyka. Prepozyt Marcin Kłoczyński był również dobrym gospodarzem; dbał o stan pomieszczeń klasztornych i wszystkich jego budynków, oraz o ich wygląd i wygodę użytkowania. Dokonywał też remontów budynków znajdujących się we wsiach należących do klasztoru oraz wznosił nowe, stosownie do potrzeb konwentu. Dużym staraniem otaczał

\footnotetext{
62 Ibidem, k. 25.

63 Ibidem, k. 25v.

64 Ibidem, k. 26.

65 Itaque Anno Domini 1612 Sabatho ante Dominicam Quinquagesimae, ad Ecclesiam SS. Corporis Christi solemniter introductus. Habitum regularem suscepit et portavit, non tamen nisi sexto post introductionem suam anno, professionem Canonicam fecit, zob. ibidem, k. 26.

66 Ibidem, k. 27v.

${ }^{67}$ Ibidem, k. 28.
} 
również sprawy reguły zakonnej i życia duchowego ${ }^{68}$. Dbał o formację młodych zakonników w okresie nowicjatu i wprowadził stanowisko lektora filozofii i teologii, organizował też w kościele Bożego Ciała publiczne dysputy w dzień św. Augustyna. Był również zwolennikiem zachowywania postów i skromności oraz prostoty życia wśród zakonników, w czym sam dawał przykład ${ }^{69}$. Swoim postępowaniem zyskał sobie przychylność przełożonych, którzy powierzali mu wiele różnych godności kościelnych, także zewnętrznych. Do zakonu kanoników wstępowało teraz więcej nowych zakonników i cieszył się on jak najlepszą opinią, co owocowało również nowymi fundacjami na rzecz klasztoru; Ranatowicz wymienia tu takie miejscowości jak Bychów, Krzemienica, Sucha, Wolbrom oraz Antokol w Wilnie. Okres rządów Marcina Kłoczyńskiego ocenił kronikarz bardzo dobrze: Sub huius felici gubernatione, caetus Canonicorum, maxime propagari et maiora in dies incrementa sumere coepit $^{70}$. W roku 1640 dodany został prepozytowi koadiutor w osobie księdza Jacka Liberiusza, doktora teologii i ówczesnego lektora filozofii w klasztorze Bożego Ciała ${ }^{71}$. Marcin Kłoczyński zmarł 8 lutego 1644 roku. Przy okazji zamieszczenia informacji o jego śmierci Ranatowicz jeszcze raz podkreślił, że czas jego prepozytury był bardzo pomyślny i owocny dla zakonu: Vir insignis. Cuius cum tota praepositura prosperum haberet successum, hoc unum defuit, ut diutius in munere praepositurae versaretur longiorique temporis spatio ipsius officium compleretur ${ }^{72}$. Jego następca na stanowisku prepozyta, Jacek Liberiusz, ufundował dla niego tablicę nagrobną, której treść została przytoczona w Kronice: Admodum Reverendo Domino Martino Kłoczyński I.V.D. Ecclesiae Conventusque huius praeposito, ac Iudicii synodali. Viro in omni vita sua integerrimo ac inculpato. In laboribus Ecclesiasticis indefesso. In sententia ferenda recto. In promovenda regulari disciplina ferverventissimo. Qui Ecclesiam hanc, varia pretiosa supellectili, Monasterium permultis aedificiis: Congregationem plurium Monasteriorum coloniis: in magnum quoque Ducatum Lituaniae ex hoc coenobio deductis, ampliavit et illustravit. Obiit plenus dierum ac meritorum. Anno Domini M.DC.XL.IV Die VIII Februarii. Aetatis 82. Perge Viator, similesque Praepositos, Huic Ecclesiae Apprecare ${ }^{73}$. W dalszej części rozdziału wspomniano osoby pochodzące z Kazimierza i mogące poszczycić się chwalebnymi dokonaniami w dziedzinie nauki oraz pracy na rzecz miasta i zakonu, wśród nich na przykład późniejszy prepozyt Jacek Liberiusz oraz Paweł Pukal, autor Genealogii Kanoników Regularnych Laterańskich ${ }^{74}$. Wśród opisywanych następnie różnych wydarzeń po raz kolejny zostały odnotowane zamieszki

\footnotetext{
68 Ibidem, k. 29.

69 Ipse ab omni luxu, ambitione, servorum strepitu, aliaque mundana ostentatione, remotus; abstinentiaque clarus, zob. ibidem, k. 29v.

70 Ibidem, k. 29v.

71 Ibidem, k. 32.

72 Mąż znakomity. Gdy cała jego prepozytura miała pomyślny i korzystny przebieg, jednego tylko zabrakło, aby dłużej spełniał obowiązki prepozyta i przez dłuższy czas sprawował swój urząd, tłum. własne autorki, zob. ibidem, k. 33 .

73 Wielce czcigodnemu Marcinowi Kłoczyńskiemu, doktorowi obojga praw, prepozytowi tego kościoła i klasztoru. Mężowi w całym swym życiu nieposzlakowanemu i nienagannemu. W pracach kościelnych niestrudzonemu. W sprawowaniu sądów prawemu. Gorliwemu w rozszerzaniu dyscypliny zakonnej. Który ten kościół różnymi cennymi naczyniami, a klasztor wieloma budowami uświetnił i ozdobił: kongregację licznymi filiami klasztoru powiększył, także w Wilekim Księstwie Litewskim, z tego klasztoru wywodzącymi się. Zmarł w pełni zasług, Roku Pańskiego 1644, dnia 8 lutego, w wieku 82 lat. Przystań, przechodniu, i módl się o podobnych prepozytów dla tego kościoła, tłum. własne autorki, zob. ibidem, k. 33.

74 Ibidem, k. 30v.
} 
i przestępstwa dokonane w Krakowie przez Żydów, które tym razem miały miejsce w roku 1636 oraz poruszona została sprawa wybudowania w Kazimierzu nowej synagogi w roku 1639. Odnotowany też został uroczysty wjazd króla Jana Kazimierza do Krakowa w roku 1649. W rozdziale tym zamieszczone zostały dodatkowo dwa krótkie biogramy zakonników odznaczających się wyjątkową świątobliwością ${ }^{75}$. Jednym z nich był Albertus Tarnovius Sowiński, mąż niezwykłej pobożności, trwający ustawicznie na modlitwie i medytacjach. Oddawał się on też częstym postom oraz pokucie i umartwieniu ciała. Zmarł w klasztorze w Suchej w roku 1636 i tam został pochowany. Drugim opisanym zakonnikiem był Mikołaj z Radomska. Również żył w wielkim ubóstwie, żywiąc się często chlebem i wodą, a inną żywność rozdając ubogim. Sam oddawał się czuwaniom i modlitwie, a także bardzo chętnie uczył innych zasad i prawd wiary chrześcijańskiej. Zmarł w roku 1610.

Ostatnim z rządców prepozytury Bożego Ciała, którego biogram Ranatowicz zamieścił w całości, był Jacek Liberiusz (1644-1673). Kronikarz od razu na początku zaznaczył, że wybór jego na stanowisko prepozyta był jednomyślny i wszyscy byli mu przychylni: [...] tanto omnium fratrum Canonicorum applauso, ut nemo fuerit, qui non ei hunc honorem gratularetur. Episcopus quoque Cracoviensis Petrus Gembicki, propensum suum erga illum animum declaravit, cum confirmationem ipsius gratam habuerit ${ }^{76}$. Podkreślił również jego dobre urodzenie i wykształcenie: studiował na Akademii Krakowskiej, gdzie zdobył tytuł magistra filozofii, a następnie doktora teologii, przebywał też przez pewien czas w Rzymie i w Mediolanie. Zyskał sobie uznanie przełożonych, gdyż powierzano mu różne ważne funkcje, między innymi został mianowany przez Andrzeja Trzebickiego, biskupa krakowskiego, cenzorem wydawanych ksiąg w diecezji krakowskiej ${ }^{77}$. Ranatowicz uznał Jacka Liberiusza również za dobrego gospodarza majątku klasztornego. Dokonywał remontów i naprawy zniszczeń spowodowanych przez wojska szwedzkie, ale też rozpoczynał nowe inwestycje i powiększał stan posiadania klasztoru, chociażby kupując na jego użytek nowe kamienice. Za jego prepozytury odnowiono i udoskonalono wiele elementów w zabudowaniach klasztornych, ponadto wzbogacony został zasób ksiąg liturgicznych w kościele Bożego Ciała. Sama świątynia była już w tym czasie ukończona, a nawet odnowiona za rządów poprzedniego prepozyta, Marcina Kłoczyńskiego, ale teraz została między innymi wybudowana nowa kaplica Matki Bożej, ustawiono nowe ołtarze, ławki oraz zainstalowano organy, które zastąpiły poprzednie, zniszczone. Powstała też na cmentarzu nowa kaplica, nazywana Ogrójcem ${ }^{78}$. Jacek Liberiusz był też według Ranatowicza dobrym zwierzchnikiem i opiekunem podległej mu parafii ${ }^{79}$. Był również gorliwym kaznodzieją, co zaowocowało wydaniem zbioru kazań dedykowanych biskupowi krakowskiemu Piotrowi Gembickiemu, pod wspólnym tytułem: Gospodyni Nieba y ziemie Naświętsza Bogarodzica Marya; innego zbioru, zatytułowanego: Gospodarz Nieba y ziemie Chrystus Jesus, który został dedykowany kolejnemu biskupowi krakowskiemu Andrzejowi Trzebickiemu oraz jeszcze jednego: Gwiazda morska, Naświętsza Panna Marya, z dedykacją dla króla polskiego Michała Korybuta. Dokonań tego prepozyta umieszczono w Kronice bardzo wiele i nie sposób wszystkich ich przytoczyć, zwłaszcza

\footnotetext{
Ibidem, k. 34v, 35 .

76 Ibidem, k. 36.

77 Ibidem, k. 36v.

78 Ibidem, k. 36v.

79 Ibidem, k. 36v.
} 
że sam autor wyraźnie się ograniczył do podania tylko najważniejszych, gdyż napisał: In summa, quidquid pro Ecclesia sua et Conventu fecit, scripsit, addixit, difficile dictu, quantum de charissima sibi sponsa merebatur ${ }^{80}$. Ranatowicz żył w przyjaźni z Jackiem Liberiuszem, jego przychylny stosunek do poczynań prepozyta widoczny jest w wielu miejscach na kartach Kroniki, choćby w samej jego ocenie: Ipse innata benignitate, prudentia, gravitate, modestia conspicuus, futurisque saeculis, et posteris invidendus, ob morum suavitatem, mansuetudinem et pudicitiam, cunctis acceptus ${ }^{81}$. Wśród różnych wydarzeń opisanych w tym rozdziale Ranatowicz wymienia na przykład spustoszenie na Rusi dokonane przez wojska kozackie pod wodzą Chmielnickiego w roku 1648; przypisuje również Kozakom zamordowanie wielu mieszkańców i zakonników w Kraśniku oraz zniszczenie tamtejszego kościoła i klasztoru ${ }^{82}$. Zdarzenie to opowiedziane zostało bardzo dokładnie, natomiast pogrzeb króla Władysława IV oraz koronacja króla Jana Kazimierza potraktowane zostały zdawkowo, jedynie krótką notatką z podaniem daty. Wspomniana została też ogromna zaraza, która w latach 1651-1653 pochłonęła bardzo wiele ofiar; na marginesie karty podana została ilość obywateli poszczególnych miast, którzy zmarli z tego powodu ${ }^{83}$, natomiast ogółem ilość ofiar w Krakowie, Kazimierzu i okolicznych miejscowościach, została oszacowana na 35 tysięcy 638 osób. Chodzi tu zapewne o zarazę, w czasie której zmarli rodzice kronikarza. Wiele uwagi poświęcił Ranatowicz najazdowi wojsk szwedzkich pod dowództwem króla Karola Gustawa w roku 1655 i ich pobytowi w Krakowie i na Kazimierzu. Szwedzi pozostawali wtedy w klasztorze Bożego Ciała około miesiąca i dokonali wielu zniszczeń i rabunków ${ }^{84}$. Przepadło w tym czasie wiele dokumentów oraz zaginęły księgi, skradzione też zostały liczne drogocenne sprzęty i naczynia liturgiczne; miał również miejsce przypadek zbezczeszczenia Najświętszego Sakramentu, kiedy po zrabowaniu złotej monstrancji hostia została porzucona na cmentarzu. Ranatowicz wspomniał też o zrabowaniu najcenniejszych zbiorów biblioteki klasztornej, wśród nich dzieł św. Augustyna. Przy okazji opisania sprawy ustanowienia podatku nazywanego pogłównym (contributio capitalis) podany został stan liczebny parafii Bożego Ciała w roku 1661: według Ranatowicza była to liczba 1518 osób. Wspomniana została też sprawa nadania dziesięcin klasztorowi w Suchej Beskidzkiej w roku 1665, kiedy prepozytem tamtejszego konwentu był Jan Ignacy Naramowski. Dokument regulujący tę należność został wystawiony przez biskupa Andrzeja Trzebickiego; Ranatowicz skopiował go w całości w swej Kronice i umieścił jako wklejkę pomiędzy kartami 41v i 42. Zaznaczył nawet miejsce, w którym znajdowała się pieczęć biskupia ${ }^{85}$. Na odwrocie wklejki wpisany został tekst dotyczący rebelii pewnych zakonników i rozwiązania tej sprawy, nie związany jednak z zamieszczonym dokumentem. W rozdziale tym kilkakrotnie pojawiają się wzmianki dotyczące zamieszek w żydowskiej dzielnicy Kazimierza, w których często uczestniczyli studenci krakowscy.

$80 \quad$ Ibidem, k. 37.

81 Ibidem, k. 37.

82 Ibidem, k. 37v.

83 Ibidem, k. 38.

84 Ibidem, k. 38.

${ }^{85}$ Locus sigilli, zob. ibidem, wklejka pomiędzy k. 41v i 42. 
W roku 1666 prepozytowi został dodany koadiutor, a wybrano nim Wiktoryna Wereszczyńskiego ${ }^{86}$. Jacek Liberiusz zmarł w roku 1673. Ranatowicz, pisząc o jego śmierci, raz jeszcze podkreślił jego zasługi dla zgromadzenia oraz wyróżniające go cechy charakteru; opisał nawet wygląd prepozyta, określając go ostatecznie jako: toto denique habitu deco$r u s^{87}$. Na marginesie karty umieścił też dodatkową notatkę na temat pomnożenia przez Jacka Liberiusza zasobów pieniężnych pozostawionych przez jego poprzednika Marcina Kłoczyńskiego ${ }^{88}$. Po śmierci Liberiusza jego następca Wiktoryn Wereszczyński ufundował w kościele Bożego Ciała tablicę poświęconą pamięci zmarłego prepozyta: Hyacinthus Liberius. Unicum Integritatis et Religionis Exemplar, Emensis in Canonico Ordine quinquaginta sex annis, omnigenarum virtutum reliquit post se vestigia. Divinioris sapientiae suffragio, ad supremam Theologici gradus lauream evectus, alienae sapientiae Censor et Arbiter esse meruit. Praepositi Generalis dignitate insignitus, eam, suavitate morum, vitae exemplo, rerum peritia, agendi gratia, per viginti novem annos, et amplius, ita administravit, ut omnium amores et laudes mereretur. Tandem laboribus et doloribus gravissimis confectus, vitam quam Ecclesiae et Religioni impenderat, naturae deposuit. Anno aetatis suae septuagesimo quarto. Christi M.DC.LXXIII. Die 23. Octobris ${ }^{89}$.

W spisie zakonników zmarłych za prepozytury Jacka Liberiusza, przy nazwiskach niektórych braci, często wymienione zostały ich szczególne dokonania i zasługi, sprawowane funkcje oraz ogólnie różne znane autorowi informacje na temat ich życia. Sytuacja taka dotyczy na przykład nekrologu Walentyna Świechowicza (+1667), Krzysztofa Łoniewskiego (+1656), Piotra Śmiarowskiego (+1655) czy Jana Gelazego Żórawskiego (+1645). Większość spośród nich Ranatowicz znał osobiście. Natomiast przy nekrologu jego rodzonego brata, Augustyna, nie ma żadnej wzmianki na temat łączącego ich pokrewieństwa ${ }^{90}$. Być może był to zabieg celowy, jako że zakonnik w ówczesnym pojęciu powinien był umrzeć dla świata, pozbyć się kontaktów z dotychczasowym życiem, a znakiem tego było przybranie nowego imienia przy obłóczynach. W każdym razie na temat swojej rodziny kronikarz prawie w ogóle nic nie pisał, a w każdym razie nie podkreślał w żaden sposób swoich powiązań rodzinnych, nawet jeśli wymieniał w Kronice kogoś ze swych bliskich.

Ostatnim spośród rządzących klasztorem Bożego Ciała opisanych w Kronice był Wiktoryn Wereszczyński (1673-1694). Ranatowicz nie wpisał już jednak jego biogramu, gdyż sam zmarł jeszcze za życia prepozyta. Po sporządzeniu karty tytułowej żywota oraz wpisaniu nazwiska, zostawił wolne miejsce na opis dokonań. Następnie, jak w poprzednich życiorysach, zrelacjonował różne wydarzenia, które miały miejsce w okresie prepozytury Wereszczyńskiego. Zaczął również wpisywać nekrologi zakonników, którzy zmarli w tym okresie,

\footnotetext{
86 Ibidem, k. 42v.

87 Ibidem, k. 44.

88 Ibidem, k. 44.

89 Jacek Liberiusz. Przykład wyjątkowy prawości i pobożności. Przeżywszy w zakonie kanoników 56 lat, pozostawił po sobie znaki wszelkiego rodzaju cnót. Z pomocą boskiej mądrości, do chwały najwyższego stopnia w teologii wyniesiony, z powodu innej wiedzy zasłużył by być cenzorem i sędzią. Wyróżniony godnością prepozyta generalnego, którą, łagodnością obyczajów, przykładem życia, doświadczeniem we wszelkich sprawach ze względu na swe działania, przez 29 lat i więcej, tak sprawował, że zasłużył na miłość i pochwały wszystkich. Aż wyczerpany trudami i ciężkim cierpieniem, życie, które kościołowi i zakonowi poświęcił, złożył naturze, w wieku 74 lat. W Roku Pańskim 1673, dnia 23 października, tłum. własne autorki, zob. ibidem, k. 44.

90 Augustinus Floridus Ranothowicz. Casimiriensis, professus domus nostrae, presbyter. Obiit in Conventu Cremenecensi. Anno Domini 1657, die 8 Julii. In Religione anno 19, zob. ibidem, k. 46v.
} 
ale nie dokończył. Zarówno po sporządzeniu notatek z lat przypadających na rządy tego prepozyta, jak i po wykazie zmarłych braci, pozostawił wiele pustych kart przeznaczonych do uzupełnienia w kolejnych latach. Przeszkodziła mu w tym śmierć, gdyż, jak wiadomo, zmarł w roku 1694. Ranatowicz planował zapewne kontynuację i jakieś zakończenie Kroniki, na co wskazuje choćby właśnie pozostawienie pustego miejsca po życiorysie ostatniego z opisanych prepozytów. Wprawdzie sam biogram został wpisany przez innego autora, to jednak wiele informacji na temat działalności Wiktoryna Wereszczyńskiego Ranatowicz zawarł w relacji z poszczególnych wydarzeń. Wiadomo stąd na przykład o konsekracji ołtarza w kaplicy Matki Bożej oraz innego w kaplicy na cmentarzu ${ }^{91}$. Pojawiają się też liczne wzmianki na temat dysput publicznych organizowanych w kościele Bożego Ciała. Odnotowany również został wyjazd prepozyta na Litwę na zgromadzenie kapituły generalnej, które miało miejsce w roku 1685 w klasztorze krzemienieckim ${ }^{92}$. Wiele miejsca poświęcił kronikarz opisowi zarazy, która w roku 1678 spowodowała śmierć ogromnej liczby osób na Kazimierzu ${ }^{93}$ oraz innym klęskom elementarnym, jak powodzie, susza lub pożar. Od karty 54, dokładnie od opisu wydarzeń z roku 1683, Ranatowicz przeszedł na język polski, którą to relację kontynuował aż do wykazu zakonników zmarłych w tym czasie. Opis ten dotyczy sposobu ubierania się zakonników w różnych zgromadzeniach, na przykład bernardynów i karmelitów ${ }^{94}$. Wymieniając zmarłych braci, Ranatowicz często podawał dodatkowe informacje, na przykład dotyczące sposobu, w jaki odeszli z tego świata i inne; zapewne były to wydarzenia, o których wiedział z bezpośredniej relacji świadków ${ }^{95}$. Zdążył jeszcze zanotować, że w 1693 roku Wiktoryn Wereszczyński zapadł na poważną chorobę i poproszono o wyznaczenie koadiutora; wybrany został Michał Rusiecki, wtedy prepozyt konwentu wileńskiego, w późniejszych latach w klasztorze Bożego Ciała na Kazimierzu (1694-1706). Na samym końcu tego rozdziału, po szeregu kart niezapisanych, znajduje się jeszcze zapomniana wcześniej informacja, opatrzona wzmianką: to się pisze teraz, co się opuścito na swym miejscu, dotycząca procesu pewnego cechu szewców z proboszczem Bożego Ciała, którym był wówczas jeszcze Marcin Kłoczyński, w roku $1640^{96}$.

Każdą z relacji o dokonaniach poszczególnych prepozytów zamyka wykaz zakonników zmarłych za jego rządów. Oczywistym jest, iż większa ilość informacji o życiu i dokonaniach zmarłych braci została podana przy zgonach z lat późniejszych, bliższych bądź współczesnych kronikarzowi. Wielu z zakonników znał bowiem osobiście, o innych słyszał niejedno od współbraci. Z pewnością też, zwłaszcza przy wpisach z lat wcześniejszych, posługiwał się nekrologiem klasztornym. Ogółem Ranatowicz wymienił w nekrologach 320 zmarłych kanoników, w tym 50 z konwentu kraśnickiego, przy czym należy do listy wpisanych do

\footnotetext{
91 Ibidem, k. 51v.

92 Ibidem, k. 56.

93 Ibidem, k. 53, 53v.

94 Ibidem, k. 54.

95 Jan Ignacy Naramowski, zmarł w wyniku pożaru w roku 1677; Jacek Wyczawski, zmarł w roku 1678 na zarazę opatrując sakramentami chorych; Benedykt Adam Samotulski, zmarł śmiercią nagłą w roku 1686, zob. ibidem, k. 57.

96 Ibidem, k. 80.
} 
Kroniki dodać jeszcze dwóch wpisanych już po śmierci jej autora ${ }^{97}$. Dodatkowo zdarzają się wpisy zmarłych benefaktorów klasztoru kazimierskiego ${ }^{98}$.

Jak wynika z lektury biogramów prepozytów, autor nie ograniczył się jedynie do podania faktów z życia zakonnego. Jego relacje zawierają bowiem wiele cennych informacji dotyczących wydarzeń w Krakowie oraz w całej Rzeczypospolitej, a także stanowią cenne źródło do badań nad kulturą oraz sprawami życia codziennego i religijnego siedemnastowiecznego Krakowa oraz Kazimierza.

\section{Report from the Chronicle by Stefan Ranatowicz CRL (1617-1694) on biographies of provosts of the Corpus Christi monastery of Canons Regular of Lateran - Krakow Congregation (from Konrad Aleman to Wiktoryn Wereszczynski) Summary}

The presented article is a discussion of biographies of 13 subsequent provosts of the monastery of Canons Regular of Lateran of Krakow Congregation, at the Corpus Christi church in Kazimierz district. The author of the chronicle, father Stefan Ranatowicz, lived in the years 1617-1694, in Kazimierz near Krakow, where he learned at the parish school at the Corpus Christi church and studied at the Krakow Academy (in the years 1635-1636). In the autumn of 1636, he joined the congregation of Canons Regular of Lateran. He was one of the leading historiographers of his order. His most important work is the Chronicle with the Latin title: Casimiriae civitatis, urbi Cracoviensi confrontatae, origo. In eaque ecclesiarum erectiones et religiosorum fundationes, nec non series, vitae, res gestae praepositorum Conventus Canonicorum Regularium Lateranensium S[ancti] Augustini ad Ecclesiam S[acratis]S[imi] Corporis Christi descriptae a Stephano Ranothowicz eiusdem conventus et Ecclesiae Canonico Regul[ari] professo. Its main section contains biographies of provosts of the Krakow monastery, from Konrad Aleman to Wiktoryn Wereszczyński. Apart from topics related directly with monastic matters, the author also discussed many issues relating to daily, religious, as well as cultural life of Kazimierz and Krakow, and also often mentioned social and economic matters concerning also the entire Polish State.

Keywords: Historiography, regular canon, biography, historical and cultural events.

Nota o Autorze: dr Małgorzata Pęgier - asystent w Katedrze Nauk Pomocniczych Historii w Instytucie Nauk Historycznych UKSW. Zainteresowania naukowe: siedemnastowieczne polskie piśmiennictwo klasztorne, historiografia klasztorna, łacińskie piśmiennictwo nowożytne.

97 Ibidem, k. 58v.

98 Ibidem, k. 10v. 